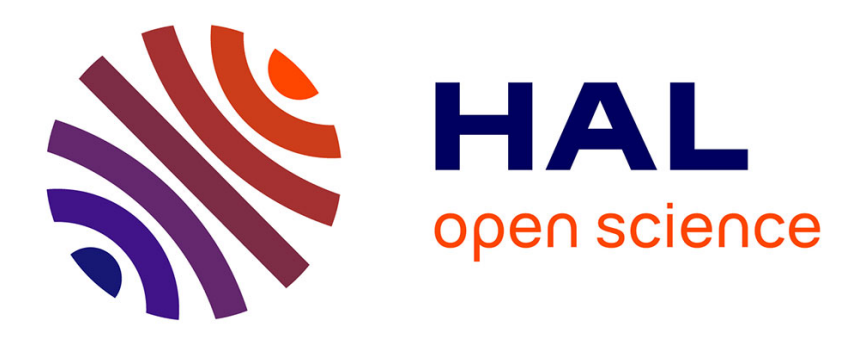

\title{
Sexual relations between seniors living with HIV
} M Banens

\section{To cite this version:}

M Banens. Sexual relations between seniors living with HIV. Sexologies, 2016, 25 (3), 10.1016/J.sexol.2016.06.002 . halshs-01368975

\section{HAL Id: halshs-01368975 https://shs.hal.science/halshs-01368975}

Submitted on 22 Sep 2016

HAL is a multi-disciplinary open access archive for the deposit and dissemination of scientific research documents, whether they are published or not. The documents may come from teaching and research institutions in France or abroad, or from public or private research centers.
L'archive ouverte pluridisciplinaire HAL, est destinée au dépôt et à la diffusion de documents scientifiques de niveau recherche, publiés ou non, émanant des établissements d'enseignement et de recherche français ou étrangers, des laboratoires publics ou privés. 
Sexologies (2016) 25, e51-e55

\title{
SEXUAL RELATIONS BETWEEN SENIORS LIVING WITH HIV / AIDS
}

Original French Title: Les relations sexuelles des seniors vivant avec le VIH

\author{
M. Banens \\ Centre Max Weber - CNRS, Université Lyon (France) \\ Maks.Banens@univ-lyon2.fr
}

The article investigates the sexual activity of seniors living with HIV, as well as their domestic and social situation. The sexual activity of HIV-positive seniors is a major concern because the HIV-positive population is rapidly ageing. Being sexually active is assumed to be one dimension of well-being and social integration. More or less closely associated with conjugality, it also provides information on possible care-givers to the HIV-positive older population as and when the need arises. A sample of 125 HIV-positive individuals, monitored by one of the hospitals of the COREVIH Vallée du Rhone (one of the donors of the research program), have been questioned, of whom 80 answered a questionnaire and 45 gave in-depth interviews. In total 80 seniors (50 years or more) were studied and compared to 45 HIV-positives of younger age. Respondents were selected randomly according to their hospital appointments, but the response rate was too low to consider the sample as representative. However, it has been possible to form four sub-groups with distinct features: heterosexual men tend to continue living within their family circle (wife, children, and sometimes grandchildren), but in conflict and without sexual activity. Heterosexual women mostly live on their own, as they did at the time of infection, but they remain on good terms with their children. Homosexual men often live in a harmonious and affectionate, but rarely sexual, seroconcordant relationship formed after the HIV diagnosis. Finally, bisexual men often live on their own, without any sexual activity and in conflict with their children and ex-partners. They turn out to be the most isolated and psychologically fragile sub-group of the survey.

Key words: Sexual relationships, HIV, Seniors, Bisexuals, Heterosexuals

\section{Introduction}

The seropositive population is ageing. Nearly one out of every two HIV positive individuals is over fifty years of age (Lert et al, 2013 ; UNAIDS, 2013). The ageing process affects HIVseropositive people as a group, but also each individual, because the accelerated physiological ageing process seems to be an accepted fact. (Morlat, 2014, Iwugi, 2013). In view of this double 
ageing process, it is important to have data on the living conditions of the senior HIV-positive population (ANRS, 2009; Group SOS, 2013). We conducted our survey by questioning older adults who are monitored in the COREVIH hospitals in the Rhône Valley (see details below). This article covers one of the aspects of social functioning: the sexual activity of HIV-positive seniors.

A number of research projects have shown the interaction between sexual activity, marital satisfaction and psychological well-being of the elderly (Trudel et al, 2013; Trudel et al, 2014; Widmer et al, 2014). Being sexually active seems positively linked to psychological well-being and marital satisfaction. However, this remains to be verified for HIV-positive seniors.

Sexual activity of older adults is actually submitted to two opposite processes. On the one hand, its frequency falls as age rises (Kontula et al, 2009). On the other hand, sexual activity has significantly increased in past decades at any age over 60. Seniors now remain sexually active until age 75 or more (Le Van et al, 2008). Yet, HIV-positive seniors not only grow older but also suffer of chronic illness and this significantly reduces sexual activity (Colson, 2016; Levinson, 2008). We expect therefore to find a poor level of sexual activity amongst the HIVpositive seniors, likely associated with a reduced level of well-being, partnership and marital satisfaction.

Lovejoy et al. (2008) actually observed low levels of sexual activity amongst HIV-positive seniors; in their survey, only $38 \%$ had been sexually active during the last three months. Men having sex with men (MSM) were found to be close to average (36\%), women were well under average $(21 \%)$, and heterosexual men were high above average $(72 \%)$. The study found the well-known dichotomy between the well-to-do, white MSM on one side, the heterosexual men and women living in poor circumstances on the other (Joyce et al, 2005), but paradoxically, sexual activity appeared high among heterosexual men, in spite of their uncertain living conditions and health problems.

Golub et al. (2009) confirmed the low level of sexual activity among HIV-positive seniors, but did not note the preservation of sexual activity among heterosexual men.

In France, the VESPA 2 (Lert et al, 2013) survey did not distinguish between seniors and adults under 50. However, nothing indicates a favourable situation for heterosexual men. Taken over all ages, heterosexual men were less sexually active than MSM. This doesn't exclude an inverse situation over age 50, but there is no indication for this assumption in the VESPA 2 survey. 
It actually is of the assumptions of Isabelle Wallach (Wallach, 2011, Wallach et al., 2013). She observed a rapid fall in sexual activity among older MSM's, and suggested this could be due to a pronounced ageism within the gay community.

The qualitative study of Desesquelles et al. (2013) came to a different conclusion. According to these authors, HIV-positive seniors are "doing fine", except women, who were found to be more isolated, both emotionally and socially. Their situation was characterized as "the lonely widow" whose "suffering cannot be eased because of feelings of betrayal" (Desesquelles et al, 2013: 55). Social isolation, psychological suffering and a low level of sexual activity would be the common lot of HIV-positive women.

\section{Data and methods}

Our survey Ageing with HIV was conducted by questioning seniors monitored in one of the COREVIH hospitals situated in the Rhône Valley (Banens et al, 2015). In total, 127 persons participated in the survey, 45 through in-depth interviews (lasting 1.5 to 2 hours), and 82 through questionnaires. The participants were divided as follows: $41 \%$ homosexual men, $11 \%$ bisexual men, $22 \%$ heterosexual men, $26 \%$ heterosexual women. All the interviews were carried out with "seniors" (50 years of age or over). Of the received questionnaires, 35 respondents were seniors, the others formed a control group for purposes of comparison. On average, the seniors were "young": $80 \%$ were between 50 and 65 years of age. This relative "youth" was the case for more than $95 \%$ of the women and the homo- and bi-sexual men. The heterosexual men on the other hand were substantially older: $42 \%$ were over 65 .

\section{Results}

Forty percent of the older adults state that they have a sexual partner. The level of sexual activity is low compared to the general population (Bajos et al, 2008), a fact confirmed by Lovejoy et al. (2008) and Wallach (2013). However, in our survey, heterosexual men (32\%) were the least active, homosexual men (46\%) the most, bisexual men (40\%) and women (40\%) occupying intermediate positions.

\subsection{Homosexuel men}

For homosexual men, sexual activity seems to be independent of age: $48 \%$ are sexually active before the age of fifty, $46 \%$ after. But this apparent stability masks an important change in lifestyle. There is a spectacular increase in homosexuals living in cohabiting partnerships after the age of 50 . Before that age, they do so for $32 \%$, but this proportion almost doubles after the 
age of $50(56 \%)$ A large number of men are thus opting for a cohabiting relationship, most of the time with another HIV-positive men: HIV-seroconcordant couples before the age of 50 represent $13 \%$ of all couples; the proportion is $71 \%$ after the age of 50 . Another distinctive feature is that many of the partners are not or no longer sexual partners.

Many homosexual respondents separate sexuality and affection. Igor, 62 years old: "Your emotional life is one thing, sex is something else." They often establish a direct link with age. Henri, 54: "When I hit 40 I said to myself.... you need to settle down, you have done it all now." They find the emotional stability within the group of HIV-positive men. Gabriel, 55 years old: "Never again will I invest in a partner who is not HIV-positive himself."

The majority of older HIV-positive homosexuals have an emotional - not always sexual relationship, a minority leads a solitary life. Among them, casual sex is rare. Joël, 54: "I live as a monk." Renaud, 61 years old: "Haven't had sex for years." Hubert, 53 years old: "I have not had sex since 1977." Ageism (Wallach, 2013) is often mentioned. Henri, 54: "Not worth going to a sauna anymore, they take you for a relic".

It turns out that sexual activity clearly drops after the age of 50, whether within or outside of the couple. This is not necessarily linked with social isolation and an unsatisfying relationship. On the contrary, it may seem that domestic satisfaction acts is the new homosexual ideal (Adam, 1999), at least for homosexual seniors, and especially domestic togetherness between HIVpositive seniors.

\subsection{Heterosexual men}

Sexual activity drops rapidly for heterosexual men. $71 \%$ have a sexual partner before they reach the age of 50,32\% after the age of 50. At the same time, they continue their partnership that is rising from $50 \%$ to $58 \%$. Contrary to homosexual men, heterosexual men seldom separate from their partner when they discover that they are HIV positive, but as a result the sexual relationship often comes to an end. Emmanuel, 67 years of age: "From the moment we knew about this problem [...] she preferred not to have sexual intercourse”. Maybe the chain of events is inverse: when sexual relations end, some men go astray and look for other sexual relationships. André, 71 years old: "As long as everything was going well with my wife... but from the age of 62.... I had to look elsewhere". This scenario seems confirmed by other observations: before the age of 50, the number of seroconcordant (heterosexual) couples is low $(25 \%)$, and it still is after age 50 (27\%), indicating that marital intercourse was not very frequent between the HIV infection and the time of diagnosis. Secondly, heterosexual men are 
much older than the other groups of HIV-positive seniors, which suggests that meeting other partners started at a more advanced age.

The advanced age partially explains the decrease in sexual activity. However, marital discord within the relationship seems to be the crucial factor. Karl, 74: "Yes, OK, I'm a bastard, I slept around, that's all there is to it." The only heterosexual men having sex with their partners are those who separated after the HIV+ diagnosis and engaged in a new partnership after. However, these cases are rare.

On the whole, heterosexual men are not very active sexually, whether within or outside their relationship. Even though they live as a couple as much as homosexual men, the interaction with wife and children is far more conflictual, and their sexual activity far less frequent.

\subsection{Bisexuel men}

None of the younger bisexual HIV-positive men participating in our survey had a sexual partner and none lived with a partner. Furthermore, they reported frequent suffering of depression and poor self-esteem. Bisexual seniors did not live frequently with a partner either (20\%) and few had sexual partners $(40 \%)$.

Pierre, 81years of age, stopped all sexual activity after discovering he was HIV-positive. "I withdrew into myself." Adam, 62: "As soon as I discovered that I was HIV-positive, "makach walou” [all finished]." Cedric, 64 years old: "As far as sex is concerned, I stopped it all." All of them lived alone at the time of diagnosis. Pierre and Cedric never lived with a partner, Adam had been married before, but was divorced well before he was infected. Some of the bisexual men continued their sexual activity. Mamadou, 61 years old: "Luckily I still have sexual relations; I have girlfriends and I also have some boyfriends." For these men, their mixed relationships did not slow down as a result of HIV-positivity. Philippe, 54 years old: "I like to live with a woman...[but] with a man, it's more just a sexual thing, you have sex as you go out for a ride on a motorbike."

There are two different categories of senior bisexual men, the sexually inactive and the sexually hyper-active. Neither of these categories resemble the homosexual seniors with whom they are generally classified together as MSM. Most bisexual men are sexually inactive, and almost all live single. Bisexual seniors are probably the most isolated and psychologically fragile of all HIV-positive seniors. 


\subsection{Women}

Women have less often a sexual partner after the age of 50 (40\%) than before (60\%), whereas the proportion living with a partner remains unchanged: $40 \%$ before the age of 50, $42 \%$ after. The women generally live in a serodiscordant (73\%) relationship, as do heterosexual men and contrary to homosexual men. In our study we found that contamination by a partner is rare, contrary to the study carried out by Desesquelles et al. (2013).

A comparison between heterosexual women and men shows more complementarities than similarities. Women do not decrease their sexual activity nor their partnerships. Contamination takes place most of the time between men who live in a partnership and women living alone. After the HIV-diagnosis, men continue their family life, women continue their life single. In a minority of cases, women start a new relationship with a new partner, generally HIV-negative. These new couples are sexually active and emotionally satisfying.

Yet, most HIV-positive senior women have neither a sexual partner nor a partner. From a conjugal point of view they are isolated, but they very often have children and grandchildren, and contrary to heterosexual and bisexual men, the women report that they are on good terms with their children.

\section{Discussion}

The principal limitation of our study derives from the low representativeness of the sample. The study questioned HIV-positive individuals monitored in the hospitals of the COREVIH in the Rhône valley, but neither the level of participation nor the reasons for refusal could be estimated. The wealth of information gathered through in-depth interviews did not always compensate for the small number of participants.

Nevertheless, the analysis of the social mechanisms specific to each group of seniors show enough differences between groups and enough similarities within groups to work out hypotheses for future research.

\section{Conclusion}

The older adults participating in our study report a low level of sexual activity, as do people suffering from any other chronic disease (Colson, 2016; Levinson, 2008). But the resemblance ends there. If indeed other chronic diseases reduce sexual activity through physiological dysfunction, HIV has a direct correlation with sexuality. More important than physiological or 
psychological dysfunctions, relationship and family conflicts are the most important causes of the lack of sexual activity in older HIV-positive adults.

Heterosexual senior men have the least sexual activity, even though they live frequently with a partner. These couples stayed together after the HIV-diagnosis, but sexual activity came to an end. Their partnership if conflictual and so is the relationship with their children. If not socially, these heterosexual men are often isolated emotionally.

Heterosexual senior women have little sex and few partnerships, but when they live with a partner, they are sexually active. Although more harmonious and satisfying than the heterosexual men's partnerships, their partnerships are nevertheless rare. Most live single. Often contaminated through short non cohabiting relationships, they tend to withdraw into themselves and focus on their children.

Homosexual men quite frequently have sexual relations and cohabiting partners, but the sexual partner is not always the cohabiting partner. In most cases they started a new relationship, just like the women, but these new couples are seroconcordant, often asexual, and "open" to outside sexual activity.

However, ageism considerably reduces sexual activity outside the relationship. Sexual activity therefore decreases both inside and outside the partnership, but, paradoxically, this seems to preserve the senior partnership, built on mutual affection.

Lastly, we found few bisexual men with sexually active after the age of 50, and an even smaller number living with a partner. Yet, a small minority is sexually highly active with different partners of both genders. They probably are socially as well as emotionally the most isolated group, as the relationship with their ex-wife and children can be very conflictual.

So, although sexual activity is indeed at a low level for all seniors living with HIV, the framework and its social and psychological consequences are very different depending on whether one is a man or a woman, and for the men depending on one's sexual orientation.

The author declares that there are no conflicts of interest. 


\section{Bibliography}

Adam P. Bonheur dans le ghetto ou bonheur domestique ? Enquête sur l'évolution des expériences homosexuelles. Actes de la recherche en sciences sociales 1999 ; 128 : 5667.

ANRS. 8e Séminaire de recherche clinique sur l'infection par le VIH. Paris : ANRS ; 2009.

Bajos N, Bozon M. Enquête sur la sexualité en France. Pratiques, genre et santé. Paris : La Découverte ; 2008.

Banens M, Mendès-Leite R, Talpin J-M, Cuvillier B. Vieillir avec le VIH. Les seniors séropositifs à Lyon et dans la Vallée du Rhône. Lyon : CMW Working Paper ; 2015.

Colson M.-H. Dysfonctions sexuelles de la maladie chronique, l'état des lieux. Première partie : fréquence, impact et gravité. Sexologies 2016, 25 (1): 16-23. doi:10.1016/j.sexol.2016.01.008.

Desesquelles A, Gotman A, Micheau J, Molière E. Etude sur la prise en charge des personnes vieillissantes vivant avec le VIH/SIDA. Paris : Direction générale de la santé ; 2013.

Golub SA, Grov C, Tomassilli J. Sexual behavior among HIN+ older adults. In : Brennan M. et al. (dir). Older adults with HIV : an indepth examination of an emerging population. NY: Nova Science Publications; 2009: 43-50

Groupe SOS, SOS Homophobie, AIDES. Rapport sur le vieillissement des personnes LGBT et des personnes séropositives au VIH. 2013.

Iwuji C, Churchill D, Gilleece Y, Weiss H, Fisher M. Older HIV-Infected Individuals Present Late and Have a Higher Mortality: Brighton, UK Cohort Study. BMC Public Health 2013, 13 (1): 397. doi:10.1186/1471-2458-13-397.

Joyce G, Dana P, Goldman A, Leibowitz A, Yuhua B. A Socioeconomic Profile of Older Adults With HIV. Journal of Health Care for the Poor and Underserved 2005; 16 : 19-28.

Kontula O, Haavio-Mannila E. The impact of aging on human sexual activity and sexual desire. J Sex Res 2009, 46 (1) : 46-56.

Le Van C, Ferrand M, Levinson S, L'absence d'activité sexuelle : une singularité plurielle. In : Bajos N, Bozon M. Enquête sur la sexualité en France. Paris : La Découverte ; 2008, p. 333-355.

Lert F, Pialoux G. Prévention et réduction des risques dans les groupes à haut risque vis-à-vis du VIH et des IST. Rapport - Missions RDRs. 2010.

Lert F, Annequin M, Tron L, Aubrière C, Hamelin C, Spire B, Dray-Spira R. Situation socioéconomique des personnes vivant avec le VIH suivies à l'hôpital en France métropolitaine en 2011. Premiers résultats de l'enquête ANRS-VESPA2. Bulletin épidémiologique hebdomadaire 2013 ; 26-27: 293-99.

Levinson S. Les "difficultés" de la function sexuelle: contexts, determinant et significations. In : Bajos N, Bozon M. Enquête sur la sexualité en France. Paris : La Découverte ; 2008, p. 485-508.

Lovejoy T, Heckman T, Sikkema K, Hansen N, Kochman A, Suhr J, Garske J, Johnson C. Patterns and Correlates of Sexual Activity and Condom Use Behavior in Persons 50Plus Years of Age Living with HIV/AIDS. AIDS and Behavior 2008; 12: 943-56. 
Morlat, P. Prise en charge médicale des personnes vivant avec le VIH : actualisation 2014 du rapport 2013. Ministère des Affaires sociales, de la Santé et des Droits des femmes, 2014. http://www.sante.gouv.fr/prise-en-charge-medicale-des-personnes-vivant-avecle-vih-actualisation-2014-du-rapport-2013.html.

Trudel G, Dargis L, Villeneuve L, Cadieux J, Boyer R, Préville M. Fonctionnement conjugal, sexuel et psychologique des couples aînés vivant à domicile : les résultats d'une enquête nationale avec méthodologie longitudinale (première partie). Sexologies, 2013, 22 (4): 176-83. doi:10.1016/j.sexol.2013.03.004.

- 2014. Fonctionnement conjugal, sexuel et psychologique des couples aînés vivant à domicile : les résultats d'une enquête nationale avec méthodologie longitudinale (deuxième partie). Sexologies, 2014, 23 (2): 52-68. doi:10.1016/j.sexol.2013.03.006.

UNAIDS. HIV and aging. A special supplement to the UNAIDS report on the global AIDS epidemic 2013. Genève: UN.

Wallach I, Ducandas X, Martel M, Trottier B, Thomas R. Le VIH et le vieillissement au Québec. Une recherche qualitative sur les expériences, les difficultés et les besoins des personnes vivant avec le VIH de 50 ans et plus. Ministère de la Famille et des Aînés 2013.

Wallach I. «Je suis heureux d'avoir l'âge que j'ai » : la résilience des hommes gais âgés vivant avec le VIH au Québec. Canadian Journal of Community Mental Health 2011; 30: 157-71.

Widmer ED, Ammar N. Désir sexuel et styles d'interactions conjugales. Sexologies 2013, 22 (4): 150-58. doi:10.1016/j.sexol.2013.05.003. 